\title{
Bullying and Cyberbullying in Primary School: The Impact of Gender and Student Academic Performance
}

\author{
Ascensión Palomares-Ruiz (D), Ramón García-Perales*(D), Antonio Cebrián-Martínez (D) \\ and María Inés Martín-García \\ Department of Pedagogy, Faculty of Education of Albacete, Universidad de Castilla-La Mancha (UCLM), \\ 02071 Albacete, Spain; ascension.palomares@uclm.es (A.P.-R.); antonio.cebrian@uclm.es (A.C.-M.); \\ mariaines.martin@uclm.es (M.I.M.-G.) \\ * Correspondence: Ramon.GarciaPerales@uclm.es
}

check for

updates

Citation: Palomares-Ruiz, A.; García-Perales, R.; Cebrián-Martínez, A.; Martín-García, M.I. Bullying and Cyberbullying in Primary School: The Impact of Gender and Student Academic Performance. Sustainability 2021, 13, 7316. https://doi.org/ $10.3390 /$ su13137316

Academic Editors: Antonio Jesús Rodríguez-Hidalgo and Daniel Falla Fernández

Received: 21 June 2021

Accepted: 26 June 2021

Published: 30 June 2021

Publisher's Note: MDPI stays neutral with regard to jurisdictional claims in published maps and institutional affiliations.

Copyright: (C) 2021 by the authors. Licensee MDPI, Basel, Switzerland. This article is an open access article distributed under the terms and conditions of the Creative Commons Attribution (CC BY) license (https:// creativecommons.org/licenses/by/ $4.0 /)$.

\begin{abstract}
Background: This study examines school bullying and cyberbullying, which are unfortunate realities in our schools that require interdisciplinary, multidimensional educational interventions in order to enhance the quality of the educational process. (2) Methods: The study analyzes the results of the application of the School Harassment Questionnaire (CAES) to 494 students in the sixth year of primary school, aged between 11 and 13, in the Spanish region of Castilla-La Mancha. The results are presented for each dimension and item in the instrument, then analyzed by gender and student academic performance. (3) Results: The results indicated statistically significant differences in the variables examined, particularly in the variable Skills for Conflict Resolution. (4) Conclusions: The use of this instrument and results such as those in this study could enhance teachers' awareness of the reality of their classrooms, from the school climate to the relational conflicts that may be present. This allows teachers to look into preventive action to encourage the comprehensive development of all students, with tutorial action being essential.
\end{abstract}

Keywords: school bullying; cyberbullying; primary education; gender; academic performance

\section{Introduction}

In Spain, there is no unified legal framework that establishes the procedure to be followed by schools in situations of peer abuse. However, there are guidelines for prevention and support [1,2]. In addition, recent legislation also included a new crime of harassment indicated in Organic Law 1/2015, 30 March, which modified Organic Law 10/1995, 23 November, of the Criminal Code [3]. This new regulatory framework establishes a new type of harassment within crimes against freedom which is intended to respond to behavior that, although serious, could not be classified as coercion or threats. It covers cases in which, without necessarily having the explicit announcement of the intention to cause harm (threats), or the direct use of violence to restrict the freedom of the victim (coercion), there are repeated behaviors that undermine the freedom and perceived safety of the victim, who is subjected to constant persecution or surveillance, repeated name-calling, or other continuous acts of harassment.

Prevention and intervention protocols for bullying are the preserve of each autonomous community in Spain and are regulated differently in each case. When we talk about bullying or mistreatment between peers, we must consider deliberate, repeated physical or verbal aggression, social or psychological rejection, sexual or discriminatory assault, and harassment via the internet and social networks in which there are prevalent expressions of superiority, domination, and intimidation. Olweus (1993) [4] defines this term as that intentional and repeated behavior from students that causes harm to another, with an imbalance of power between the bully and the victim.

Bullying is influenced by internal and external factors, which are elements to bear in mind [5-7], especially in the planning and implementation of preventive strategies. It is a 
complex phenomenon due to the multiple variables that may have an impact on it [8-12]. Bullying can appear at any time during a students' educational life, so identifying it and intervening in the early stages of schooling is essential [2]. There is research that addresses this issue during primary education $[9,13,14]$, emphasizing the need to prevent situations of violence and anticipate situations of imbalance and discrimination through education. Data that support this early approach include the fact that the percentage of students at risk in Compulsory Secondary Education (ESO) and Baccalaureate stands at 32\% [15], and $49.3 \%$ of the students enrolled in ESO would have suffered from aggression at school [16].

Maintaining a proper harmonious climate at school and preventing violent behavior is essential, and tutorial action helps to achieve this goal from an early age by providing awareness of ongoing interactions and power relationships and how they operate in the social groups at school [5]. Tutoring activities focused on welcoming new students, emotional intelligence, self-concept and self-esteem, assertiveness, and social skills, among others, are considered fundamental for the prevention of violent behavior during primary education [17], even more so when faced with the difficulties that sometimes appear in the transition between primary and secondary education [18].

Among the behaviors considered bullying, cyberbullying has arisen as a result of the use of social networks and new internet technologies [19-22]. Cyberbullying is defined as threats or intimidating or threatening messages sent through computer resources. It can lead to mental disorders and behavioral disturbances [23]. Cyberbullying behaviors can spread rapidly and easily, making the victim feel more helpless and encouraging these violent manifestations to be considered trivial and even part of the normal makeup of our culture [24]. Schools must detect these situations and carry out interventions [25-27]. It is also essential for schools to help develop aspects of students' moral personalities [28] and the sense of being part of a community [29] due to their significant mediating effects, seeking to minimize the consequences as far as possible for those involved and considering an ecological-systemic perspective in the approach $[7,30]$.

The regulatory basis for intervention in Castilla-La Mancha, the Spanish region this study took place in, is the Ministry of Education, Culture, and Sport Resolution on 18 January 2017, which published the protocol for action in situations of bullying in schools in Castilla La Mancha [31]. The resolution defines bullying in the following terms [31] (p. 1179):

School bullying is a situation in which students, individually or as a group, are exposed to various forms of intentional harassment by other students repeatedly and over an extended period of time, such that the bullied students are in a situation of inferiority with respect to bullying students. This bullying leads to an imbalance that prevents bullied students from being able to get out of the situation by themselves;

Other Autonomous Communities, such as Andalucía, define the concept of school bullying similarly as "psychological, verbal, or physical abuse towards a student by one or more classmates repeatedly over a determined period of time" [32] (p. 12). Different types of abuse, whether individual or group phenomena, the consequences of it, and its persistence over time, form the basis for the conceptualization of the term;

School bullying is a social and educational problem that can have devastating consequences [33-38]. It is a real problem in our schools that hinders the academic performance of those involved [24]. The educational inclusion of all students, whatever their abilities, needs, interests, and motivations, is a key principle of equity in education, equal opportunities, and attention to diversity in schools.

Our society is progressively moving towards greater equality of opportunities, although parity between men and women still seems far from being achieved. One of the fundamental areas for egalitarian action is education [39]. One of the main purposes of education is the achievement of the greatest possible equality of opportunities for schoolchildren, regardless of gender, in order to encourage their fullest possible development through quality teaching and learning processes [40]. In this study, we examined the gender of schoolchildren as a variable of analysis for the phenomena of bullying and cyber- 
bullying to look at their impact on equality in education. Gender can be an important factor in the type of aggression in schools [41,42] as well as outside them [43]. We also examine academic performance as a variable, which is a key construct in schoolchildren's adaptive processes in education [44] and, more specifically, in situations of peer harassment [45-47]. This study aims to analyze the extent to which these variables can be predictors of bullying.

Bullying can originate from conflict in social, family, and school settings [6], hence the need to approach these phenomena of mistreatment between equals from an ecologicalsystemic perspective $[7,30]$. Due to the broad nature of the phenomenon of bullying, this study considers the impact that the socialization of gender and students' academic performance may have on how bullying and cyberbullying occur. Some research has included gender [48-51] and academic performance [51-53] variables in the understanding of bullying and cyberbullying. The current study analyzes the possible impact of these variables during primary education, which is the main theoretical hypothesis the study examines using a questionnaire designed and constructed to identify situations of peer abuse.

The general objective of this quantitative study is to analyze what sixth-year primaryschool students in Castilla-La Mancha (Spain) know about bullying by administering a specific evaluation questionnaire for this construct. The main strength of the study is that it will provide information about bullying and cyberbullying in primary-school students, as the vast majority of studies have been performed with secondary-school students. This information can also be important in the transition between educational stages and schools. Our specific objectives are to analyze the results based on two modulating variables, the gender of the students and their average academic performance across all areas of the curriculum.

\section{Materials and Methods}

\subsection{Participants}

We used stratified sampling to select a probabilistic sample of 494 schoolchildren in the sixth year of primary school, aged between 11 and 13 years old, in the Autonomous Community of Castilla-La Mancha (Spain). We chose this grade/year because it is the final year before students begin secondary education and move to secondary schools. It is a time of multiple physical, psychological, and social changes that could be key in the appearance of school aggression [24] because there are situations of imbalance that could lead to problems with school harmony and situations of peer abuse $[6,40]$.

The participating sample represented $2.27 \%$ of the school population in this region for this school year [54]. This age range is similar to that used in other studies on this topic $[9,13,14]$. The students in our study attended 14 primary schools throughout the region, proportionally distributed according to the number of students in the sixth grade, whether the school was in an urban (296 students, 59.9\%) or rural (198 students, 40.1\%) areas, and whether the school was state-funded or not, public (409 students, $82.8 \%$ ) and private or semi-private ( 85 students, $17.2 \%$ ). The distribution of the sample by gender was 240 boys (48.6\%) and 254 girls (51.4\%). Finally, it should be noted that this sample was the same as the one used for the validation of the applied questionnaire [55].

\subsection{Variables}

The terminological basis for this study comes from the Ministry of Education, Culture, and Sport Resolution from 18 January 2017, which published an action protocol for situations of bullying in schools in Castilla-La Mancha [31]. The evaluation of student knowledge about the concepts of bullying and cyberbullying, the main study variable, started from three dimensions with their respective sub-dimensions:

- Conceptualization: bullying and cyberbullying;

- Perceptions: aggressor, victim, and witness;

- Skills for conflict resolution: personal and social.

We used four additional variables to analyze our results:

- $\quad$ Gender: Male (M) or Female (F), collected via the questionnaire; 
- Average academic performance across all areas of the curriculum at the end of the school year (June 2019). The categorization in Spain is Fail (insuficiente) (IS), Satisfactory (suficiente) (SF), Good [bien] (BI), Remarkable (notable) (NT), and Excellent (sobresaliente) (SB);

- Type of school: Public (P) or Private-Semiprivate-concertado (Pr) based on the funding, schools that are funded and managed by the education authority are public;

- School setting: Urban (U) or Rural (R), schools in towns with more than 10,000 inhabitants were considered to be in an urban setting.

\subsection{Instrument}

We used the School Bullying Questionnaire (CAES) to collect the data for the study. The tool contains 40 items in order to learn what the students know about the terms bullying and cyberbullying, what they think about these concepts from the perspectives of victims, aggressors, and witnesses, and what personal and social skills they have for conflict resolution.

Content validity was ensured via expert judgment through a panel of 11 educational guidance specialist teachers with at least 10 years of experience and who had specific training in bullying, were able to participate, and worked in the same region in which the study took place. Three-quarters $(77.5 \%)$ of the items had content validity indices above 0.80 , none were below 0.25 , and the Kappa index was 0.80 . An exploratory factor analysis gave a percentage of total explained variance of $63.83 \%$ and a factorial structure similar to that designed initially, using the orthogonal varimax rotation method according to Kaiser and no items appearing correlating above 0.40 in two or more factors. According to the confirmatory factor analysis, the correlations of the items with their respective latent variables or dimensions were adequate, and there was a degree of fit of the plausible model, with CMIN values of $37.23, p=0.067$, RMSA 0.04, CFI 0.92, and TLI 0.91, confirming the fit of the established structure to the data. In terms of reliability analysis, Cronbach's Alpha for the items was 0.76 and for the dimensions 0.84 (Conceptualization 0.94, Perceptions 0.79 , and Conflict resolution skills 0.78), both of which were high and significant [55].

The structure of the instrument is displayed in Table 1.

Table 1. Instrument structure.

\begin{tabular}{ccc}
\hline Dimensions & Subdimensions & Items \\
\hline \multirow{2}{*}{ Conceptualization } & Bullying & 4 \\
& Cyberbullying & 4 \\
\hline \multirow{2}{*}{ Perceptions } & Victim & 9 \\
& Aggressor & 9 \\
Conflict resolution skills & Witness & 8 \\
\hline
\end{tabular}

Source: Authors' own work (2021).

Each item is evaluated using a five-point Likert-type scale between 1 and 5: Completely disagree (1), Disagree (2), Neither agree nor disagree (3), Agree (4), and Completely agree (5). The instrument takes about $45 \mathrm{~min}$ to complete; we also used an additional data sheet to collect information related to the variables gender and academic performance.

\subsection{Procedure}

The study took place during 2019 and 2020, following the questionnaire being administered in person. Teachers from each participating school provided information about student gender and performance. Before the study began, we sought approval and informed consent from parents or guardians, the school authorities, and the children. We ensured the anonymity of the responses and the confidentiality of all data collected, with published results not containing any school identifying information. 


\subsection{Data Analysis}

First, we calculated the descriptive statistics for each item and dimension. Subsequently, we performed comparisons of means to determine whether there were statistically significant differences according to gender and academic performance. Lastly, we compared these two variables to each other via multivariate analysis and then compared them in terms of school type and setting. All statistical analysis was done using SPSS version 24.0, software license for teaching provided by the University of Castilla-La Mancha (UCLM).

\section{Results}

The results are presented according to the general study objective, examining what sixth year primary-school students in Castilla-La Mancha know about the concept of bullying and cyberbullying, and the two specific objectives, examining the results according to the gender of the students and their average academic performance in all areas of the curriculum. Table 2 shows the results of the student responses to the questionnaire.

Table 2. Results after applying the questionnaire.

\begin{tabular}{|c|c|c|c|c|c|c|c|}
\hline \multirow{2}{*}{ Dimension (D)/ Item (I) } & \multicolumn{5}{|c|}{ Scale $(n)$} & \multirow{2}{*}{$\mathbf{M}$} & \multirow{2}{*}{ SD } \\
\hline & 1 & 2 & 3 & 4 & 5 & & \\
\hline \multicolumn{8}{|l|}{ D1: Conceptualization } \\
\hline $\mathrm{I} 1$ & 0 & 4 & 56 & 222 & 212 & 4.30 & 0.70 \\
\hline $\mathrm{I} 2$ & 8 & 42 & 172 & 222 & 50 & 3.53 & 0.85 \\
\hline $\mathrm{I} 3$ & 24 & 162 & 198 & 110 & 0 & 3.80 & 0.84 \\
\hline $\mathrm{I} 4$ & 4 & 46 & 166 & 198 & 80 & 3.62 & 0.89 \\
\hline $\mathrm{I} 5$ & 34 & 112 & 206 & 100 & 42 & 3.01 & 1.02 \\
\hline I6 & 42 & 184 & 192 & 52 & 24 & 2.66 & 0.95 \\
\hline I7 & 24 & 96 & 204 & 120 & 50 & 3.15 & 1.00 \\
\hline I8 & 20 & 104 & 208 & 100 & 62 & 3.16 & 1.03 \\
\hline Total D1 & & & & & & 3.41 & 0.75 \\
\hline \multicolumn{8}{|l|}{ D2: Perceptions } \\
\hline I9 & 436 & 40 & 18 & 0 & 0 & 1.15 & 0.45 \\
\hline $\mathrm{I} 10$ & 448 & 46 & 0 & 0 & 0 & 1.09 & 0.29 \\
\hline $\mathrm{I} 11$ & 402 & 54 & 30 & 8 & 0 & 1.28 & 0.65 \\
\hline $\mathrm{I} 12$ & 340 & 82 & 40 & 24 & 8 & 1.54 & 0.95 \\
\hline $\mathrm{I} 13$ & 372 & 96 & 26 & 0 & 0 & 1.30 & 0.56 \\
\hline $\mathrm{I} 14$ & 494 & 0 & 0 & 0 & 0 & 1.00 & 0.00 \\
\hline $\mathrm{I} 15$ & 464 & 30 & 0 & 0 & 0 & 1.06 & 0.24 \\
\hline $\mathrm{I} 16$ & 434 & 40 & 8 & 8 & 4 & 1.19 & 0.62 \\
\hline $\mathrm{I} 17$ & 304 & 56 & 78 & 36 & 20 & 1.81 & 1.18 \\
\hline I18 & 450 & 40 & 4 & 0 & 0 & 1.10 & 0.32 \\
\hline I19 & 476 & 18 & 0 & 0 & 0 & 1.04 & 0.19 \\
\hline I20 & 416 & 26 & 32 & 16 & 4 & 1.31 & 0.80 \\
\hline $\mathrm{I} 21$ & 412 & 50 & 24 & 8 & 0 & 1.25 & 0.62 \\
\hline I22 & 442 & 44 & 8 & 0 & 0 & 1.12 & 0.37 \\
\hline I23 & 494 & 0 & 0 & 0 & 0 & 1.00 & 0.00 \\
\hline I24 & 464 & 30 & 0 & 0 & 0 & 1.06 & 0.24 \\
\hline I25 & 396 & 48 & 40 & 10 & 0 & 1.32 & 0.71 \\
\hline I26 & 298 & 76 & 86 & 14 & 20 & 1.75 & 1.09 \\
\hline I27 & 336 & 102 & 48 & 8 & 0 & 1.45 & 0.73 \\
\hline I28 & 450 & 40 & 4 & 0 & 0 & 1.10 & 0.32 \\
\hline I29 & 248 & 92 & 90 & 48 & 16 & 1.97 & 1.17 \\
\hline $\mathrm{I} 30$ & 344 & 66 & 64 & 20 & 0 & 1.51 & 0.87 \\
\hline I31 & 382 & 58 & 36 & 16 & 2 & 1.38 & 0.79 \\
\hline I32 & 404 & 78 & 10 & 2 & 0 & 1.21 & 0.48 \\
\hline I33 & 494 & 0 & 0 & 0 & 0 & 1.00 & 0.00 \\
\hline I34 & 176 & 96 & 118 & 70 & 34 & 2.37 & 1.28 \\
\hline Total D2 & & & & & & 1.32 & 0.26 \\
\hline D3: Skills & & & & & & & \\
\hline
\end{tabular}


Table 2. Cont.

\begin{tabular}{|c|c|c|c|c|c|c|c|}
\hline \multirow{2}{*}{ Dimension (D)/ Item (I) } & \multicolumn{5}{|c|}{ Scale $(n)$} & \multirow{2}{*}{$\mathbf{M}$} & \multirow{2}{*}{ SD } \\
\hline & 1 & 2 & 3 & 4 & 5 & & \\
\hline I35 & 20 & 20 & 98 & 232 & 124 & 3.85 & 0.98 \\
\hline I36 & 78 & 106 & 104 & 144 & 62 & 3.01 & 1.28 \\
\hline I37 & 8 & 22 & 68 & 288 & 108 & 3.94 & 0.82 \\
\hline I38 & 74 & 104 & 108 & 162 & 46 & 3.00 & 1.23 \\
\hline I39 & 4 & 40 & 124 & 250 & 76 & 3.72 & 0.85 \\
\hline $\mathrm{I} 40$ & 8 & 22 & 74 & 250 & 140 & 4.00 & 0.87 \\
\hline Total D3 & & & & & & 3.59 & 0.64 \\
\hline Total & & & & & & 2.77 & 0.55 \\
\hline
\end{tabular}

Source: Authors' own work (2021).

Table 2 shows that there were high scores for the Conceptualization dimension, particularly for Item 1 , the concept of bullying in the school bullying subdimension, which had the highest mean score $(4.30 ; \mathrm{SD}=0.70)$ in the instrument. The Conceptualization dimension also includes the Cyberbullying subdimension, which had lower scores than the Bullying subdimension, the lowest being Item 6 , knowledge of the dangers of social networks $(2.66$; $\mathrm{SD}=0.95)$.

The highest scoring item in the Perceptions dimension was Item 34 , about witnessing rejection or isolation on social networks or the internet, with a mean value of 2.37 ( $\mathrm{SD}=1.28$ ). It is worth noting that Items 14 ("I have been a victim of touching"), 23 ("I have touched colleagues"), and 33 ("Have you ever seen a colleague being sexually harassed") had scores of $1(\mathrm{SD}=0.00)$ as all of the participants gave those items the lowest score possible. Due to the lack of variation in the results for these three items, they were eliminated from the subsequent analyses.

The highest score in the Skills dimension was in Item 40, related to having friends in and out of school, with a mean of $4.00(\mathrm{SD}=0.87)$. The lowest scoring items in the skills dimension were Items 36 ("I like to make decisions") and 38 ("I like to be the leader in my group of friends") with means of $3.01(\mathrm{SD}=1.28)$ and $3.00(\mathrm{SD}=1.23)$, respectively.

Finally, the mean scores for each dimension were as follows: Conceptualization 3.41 $(\mathrm{SD}=0.75)$, Perceptions $1.32(\mathrm{SD}=0.26)$ and Skills $3.59(\mathrm{SD}=0.64)$. The mean for the whole questionnaire was $2.77(\mathrm{SD}=0.55)$.

Once the results from the questionnaire were calculated, we analyzed them in terms of gender and academic performance. The distribution of the sample was $240(48.6 \%)$ boys and $254(51.4 \%)$ girls. We used a $t$-test for independent samples to determine differences in the results with respect to this variable. The results are shown in Table 3.

We found statistically significant differences in the Conceptualization dimension in Items $1(p=0.002, \mathrm{~d}=0.28), 4(p=0.001, \mathrm{~d}=0.29), 5(p=0.022, \mathrm{~d}=0.21)$, and 8 $(p=0.029, \mathrm{~d}=0.19)$ and for the total dimension $(p=0.015, \mathrm{~d}=0.23)$, with girls exhibiting greater knowledge of the concepts of bullying and cyberbullying. There were statistically significant differences in the Perceptions dimension in Items $9(p=0.027, \mathrm{~d}=0.20)$ and $13(p=0.001, d=0.29)$, the Victim subdimension, where boys had higher scores. In the Aggressor subdimension, we found differences in Items $19(p<0.001, \mathrm{~d}=0.32), 20(p<0.001$, $\mathrm{d}=0.45), 21(p<0.001, \mathrm{~d}=0.41), 22(p<0.001, \mathrm{~d}=0.47), 24(p<0.001, \mathrm{~d}=0.57), 25$ $(p<0.001, \mathrm{~d}=0.39)$, and $26(p=0.002, \mathrm{~d}=0.41)$, with boys scoring higher. In the Witness subdimension, we found differences in Items $27(p<0.001, \mathrm{~d}=0.61), 28(p=0.041, \mathrm{~d}=0.19)$, and $30(p<0.001, d=0.40)$, with boys again scoring higher. In the total of the Perceptions dimension, it was clear that the boys had a better sense of the subdimensions in this category $(p<0.001, \mathrm{~d}=0.43)$, bullying and cyberbullying from the point of view of the Victim, Aggressor and Witness are phenomena that primarily seem to affect boys, with moderate effect sizes. Given the non-normal distribution of the results according to the gender variable for the items in dimension 2, we performed a non-parametric chi-square test. The results gave values similar to those indicated in Table 3, with statistical significance, 
$p<0.05$, in items $9,13,19,20,21,22,24,25,26,27,28,30$, and Total. In this regard, it is worth noting item 11 , which had a $p$ value $=0.029$ following the chi-square test, whereas in Table 3 the $t$-test produced a value of 0.072 . There were no statistically significant values for the remaining items in this dimension.

Table 3. Results of $t$-test for independent samples based on gender.

\begin{tabular}{|c|c|c|c|c|c|c|c|c|}
\hline \multirow{2}{*}{ Dimension (D)/ Item (I) } & \multicolumn{2}{|c|}{ Male } & \multicolumn{2}{|c|}{ Female } & \multirow{2}{*}{$\mathbf{t}$} & \multirow{2}{*}{ df } & \multirow{2}{*}{$p$-Value } & \multirow{2}{*}{ d } \\
\hline & $\mathbf{M}$ & SD & $\mathbf{M}$ & SD & & & & \\
\hline \multicolumn{9}{|l|}{ D1: Conceptualization } \\
\hline I1 & 4.20 & 0.74 & 4.39 & 0.64 & -3.11 & 492 & $0.002^{* *}$ & 0.28 \\
\hline $\mathrm{I} 2$ & 3.48 & 0.82 & 3.59 & 0.87 & -1.51 & 492 & 0.130 & 0.13 \\
\hline I3 & 3.75 & 0.82 & 3.84 & 0.86 & -1.22 & 492 & 0.221 & 0.11 \\
\hline $\mathrm{I} 4$ & 3.48 & 0.94 & 3.74 & 0.83 & -3.23 & 492 & $0.001^{* *}$ & 0.29 \\
\hline I5 & 2.90 & 0.98 & 3.11 & 1.05 & -2.29 & 492 & $0.022 *$ & 0.21 \\
\hline I6 & 2.63 & 0.90 & 2.69 & 0.99 & -0.80 & 492 & 0.427 & 0.06 \\
\hline I7 & 3.07 & 1.06 & 3.24 & 0.95 & -1.87 & 492 & 0.061 & 0.17 \\
\hline I8 & 3.06 & 1.00 & 3.26 & 1.05 & -2.19 & 492 & $0.029 *$ & 0.19 \\
\hline Total D1 & 3.32 & 0.74 & 3.49 & 0.75 & -2.45 & 492 & 0.015 * & 0.23 \\
\hline \multicolumn{9}{|l|}{ D2: Perceptions } \\
\hline I9 & 1.20 & 0.48 & 1.11 & 0.42 & 2.22 & 492 & 0.027 * & 0.20 \\
\hline $\mathrm{I} 10$ & 1.11 & 0.31 & 1.08 & 0.27 & 1.13 & 492 & 0.259 & 0.10 \\
\hline I11 & 1.33 & 0.74 & 1.23 & 0.55 & 1.80 & 492 & 0.072 & 0.15 \\
\hline $\mathrm{I} 12$ & 1.54 & 1.00 & 1.54 & 0.90 & 0.07 & 492 & 0.942 & 0.00 \\
\hline $\mathrm{I} 13$ & 1.38 & 0.61 & 1.22 & 0.50 & 3.25 & 492 & $0.001^{* *}$ & 0.29 \\
\hline $\mathrm{I} 15$ & 1.08 & 0.26 & 1.05 & 0.21 & 1.29 & 492 & 0.197 & 0.13 \\
\hline I16 & 1.23 & 0.76 & 1.16 & 0.44 & 1.36 & 492 & 0.174 & 0.11 \\
\hline $\mathrm{I} 17$ & 1.91 & 1.25 & 1.72 & 1.11 & 1.81 & 492 & 0.071 & 0.16 \\
\hline I18 & 1.12 & 0.37 & 1.08 & 0.27 & 1.31 & 492 & 0.192 & 0.12 \\
\hline I19 & 1.07 & 0.25 & 1.01 & 0.09 & 3.52 & 492 & $0.000^{* * *}$ & 0.32 \\
\hline I20 & 1.49 & 1.01 & 1.14 & 0.47 & 4.99 & 492 & $0.000^{* * *}$ & 0.45 \\
\hline I21 & 1.38 & 0.75 & 1.13 & 0.42 & 4.57 & 492 & $0.000^{* * *}$ & 0.41 \\
\hline $\mathrm{I} 22$ & 1.21 & 0.48 & 1.04 & 0.19 & 5.16 & 492 & $0.000^{* * *}$ & 0.47 \\
\hline $\mathrm{I} 24$ & 1.13 & 0.33 & 1.00 & 0.00 & 6.01 & 492 & $0.000^{* * *}$ & 0.57 \\
\hline I25 & 1.46 & 0.79 & 1.19 & 0.60 & 4.30 & 492 & $0.000^{* * *}$ & 0.39 \\
\hline I26 & 1.98 & 1.30 & 1.54 & 0.80 & 4.56 & 492 & $0.000^{* * *}$ & 0.41 \\
\hline I27 & 1.67 & 0.84 & 1.24 & 0.54 & 6.66 & 492 & $0.000^{* * *}$ & 0.61 \\
\hline $\mathrm{I} 28$ & 1.07 & 0.25 & 1.13 & 0.38 & -2.05 & 492 & 0.041 * & 0.19 \\
\hline I29 & 1.96 & 1.17 & 1.98 & 1.17 & -0.25 & 492 & 0.806 & 0.02 \\
\hline $\mathrm{I} 30$ & 1.69 & 0.97 & 1.35 & 0.73 & 4.50 & 492 & $0.000 * * *$ & 0.40 \\
\hline I31 & 1.35 & 0.78 & 1.40 & 0.80 & -0.72 & 492 & 0.469 & 0.06 \\
\hline I32 & 1.22 & 0.47 & 1.20 & 0.49 & 0.27 & 492 & 0.783 & 0.04 \\
\hline I34 & 2.36 & 1.29 & 2.39 & 1.28 & -0.24 & 492 & 0.812 & 0.02 \\
\hline Total D2 & 1.38 & 0.29 & 1.27 & 0.22 & 5.01 & 492 & $0.000^{* * *}$ & 0.43 \\
\hline \multicolumn{9}{|l|}{ D3: Skills } \\
\hline I35 & 3.55 & 1.15 & 4.13 & 0.67 & -6.95 & 492 & $0.000^{* * *}$ & 0.62 \\
\hline $\mathrm{I} 36$ & 2.12 & 0.99 & 3.86 & 0.89 & -20.56 & 492 & $0.000^{* * *}$ & 1.85 \\
\hline I37 & 3.77 & 0.92 & 4.11 & 0.68 & -4.73 & 492 & $0.000^{* * *}$ & 0.42 \\
\hline $\mathrm{I} 38$ & 2.18 & 1.00 & 3.78 & 0.87 & -18.93 & 492 & $0.000^{* * *}$ & 1.71 \\
\hline I39 & 3.28 & 0.82 & 4.13 & 0.65 & -12.67 & 492 & $0.000^{* * *}$ & 1.15 \\
\hline $\mathrm{I} 40$ & 3.82 & 0.97 & 4.17 & 0.73 & -4.53 & 492 & $0.000^{* * *}$ & 0.41 \\
\hline Total D3 & 3.12 & 0.48 & 4.03 & 0.42 & -22.37 & 492 & $0.000^{* * *}$ & 2.02 \\
\hline Total & 2.61 & 0.29 & 2.93 & 0.30 & -11.85 & 492 & $0.000^{* * *}$ & 1.08 \\
\hline
\end{tabular}

We found statistically significant differences in the Skills dimension in Items 35 $(p<0.001, \mathrm{~d}=0.62), 36(p<0.001, \mathrm{~d}=1.85), 37(p<0.001, \mathrm{~d}=0.42), 38(p<0.001$, $\mathrm{d}=1.71), 39(p<0.001, \mathrm{~d}=1.15), 40(p<0.001, \mathrm{~d}=0.41)$, and in the total dimension $(p=0.000, \mathrm{~d}=2.02)$. All of these differences indicated girls scoring higher than boys, suggesting that girls have better personal and social skills for managing conflict resolution 
than their male counterparts. Finally, we also found a statistically significant difference in the overall score of the questionnaire $(p<0.001, \mathrm{~d}=1.08)$, with the girls scoring higher than the boys. It is important to highlight the large effect size. Finally, a multivariate analysis between the sex variable and each dimension and the total score in the questionnaire confirmed these statistically significant differences, with values of $p<0.001$ (Concept dimension $\mathrm{F}=876.79, p=0.000$; Perception dimension $\mathrm{F}=1662.43, p=0.000$; Skills dimension $\mathrm{F}=1165.13, p=0.000$; Total $\mathrm{F}=2842.42, p=0.000$ ). Student gender is a variable to bear in mind both at the preventive level and in specific interventions in situations of bullying and cyberbullying [48-51,56].

The final variable used to examine the results was student academic performance, which is shown in Table 4.

Table 4. Academic performance of the research sample.

\begin{tabular}{ccc}
\hline Academic Performance & $\boldsymbol{n}$ & \% \\
\hline IS & 72 & 14.6 \\
SF & 84 & 17.0 \\
BI & 142 & 28.7 \\
NT & 112 & 22.7 \\
SB & 84 & 17.0 \\
\hline Total & 494 & 100 \\
\hline
\end{tabular}

Source: Authors' own work (2021).

To determine whether there were statistically significant differences between the schoolchildren in the instrument as a whole, we transformed the variable academic performance into a categorical variable divided into three levels: Low (Fail and Satisfactory, $n=156,31.6 \%$ ), Medium (Good, $n=142,28.7 \%$ ), and High (Notable and Outstanding, $n=196,39.7 \%)$. The average score in each of the categories was $2.60(\mathrm{SD}=0.33)$ for the Low level, $2.76(\mathrm{SD}=0.24)$ for the Medium level, and $2.92(\mathrm{SD}=0.34)$ for the High level. The mean value for the three categories was $2.77(\mathrm{SD}=0.34)$. Table 5 shows the results of the ANOVA for this variable. After determining the statistical significance of the differences between means, we compared between groups using the Bonferroni test (Direction column).

The ANOVA (Table 5) indicated multiple statistically significant differences. For the Conceptualization dimension, they were in Items 1, 2, 3, 5, 6, 7, and 8 and for the total dimension. In general, in this dimension, students with medium and high levels of performance exhibited greater knowledge of the concepts of bullying and cyberbullying. In the Perceptions dimension, there were significant differences in Items 9 and 10 (Victim subdimension) for high-achieving students compared to medium-performing students. There were also differences in Items 20, 24, and 26 (Aggressor subdimension) with variable differences between the three types of performance. Finally, there were also differences in Items 29, 30, and 34 (Witness subdimension), although no clear pattern, with differences in favor of the three levels of performance. We found no statistically significant differences for the overall Perceptions dimension. Due to the non-normal distribution of the items in this Perceptions dimension in relation to the academic performance variable, we performed a non-parametric chi-square test. The results gave values similar to those in Table 5, with statistical significance, $p<0.05$, for items 9, 10, 24, 26, 29, 30, and 34. It is worth highlighting items 13 and 20, with $p$ values of 0.003 and 0.000 , respectively, following the chi-square test, compared to the values following the $t$-test shown in Table 5 of 0.170 and 0.054 , respectively. The results for the remaining items indicated non-statistically significant results. Academic performance has an influence on situations of bullying and cyberbullying [51-53]. 
Table 5. ANOVA testing of academic performance.

\begin{tabular}{|c|c|c|c|c|c|c|c|c|c|c|c|}
\hline \multirow{2}{*}{$\begin{array}{c}\text { Dimension (D)/ } \\
\text { Item (I) }\end{array}$} & \multicolumn{2}{|c|}{ Low } & \multicolumn{2}{|c|}{ Medium } & \multicolumn{2}{|c|}{ High } & \multirow[b]{2}{*}{$\mathbf{F}$} & \multirow[b]{2}{*}{ df } & \multirow[b]{2}{*}{$p$-Value } & \multirow[b]{2}{*}{$\mathrm{Eta}^{2}$} & \multirow[b]{2}{*}{ Direction } \\
\hline & $\mathbf{M}$ & SD & $\mathbf{M}$ & SD & $\mathbf{M}$ & SD & & & & & \\
\hline \multirow{2}{*}{\multicolumn{12}{|c|}{$\begin{array}{c}\text { D1: } \\
\text { Conceptualization }\end{array}$}} \\
\hline & & & & & & & & & & & \\
\hline $\mathrm{I} 1$ & 4.03 & 0.77 & 4.34 & 0.63 & 4.49 & 0.61 & 21.15 & 493 & $0.000 * * *$ & 0.08 & $\mathrm{H}, \mathrm{M}>\mathrm{L}$ \\
\hline $\mathrm{I} 2$ & 3.35 & 0.95 & 3.48 & 0.79 & 3.72 & 0.77 & 9.37 & 493 & $0.000^{* * *}$ & 0.04 & $\mathrm{H}>\mathrm{M}, \mathrm{L}$ \\
\hline I3 & 3.67 & 0.92 & 3.65 & 0.79 & 4.01 & 0.76 & 10.85 & 493 & $0.000 * * *$ & 0.04 & $\mathrm{H}>\mathrm{M}, \mathrm{L}$ \\
\hline $\mathrm{I} 4$ & 3.50 & 1.02 & 3.61 & 0.78 & 3.71 & 0.85 & 2.53 & 493 & 0.081 & 0.01 & $\mathrm{H}, \mathrm{M}, \mathrm{L}$ \\
\hline I5 & 2.77 & 1.03 & 3.18 & 0.88 & 3.07 & 1.08 & 6.86 & 493 & $0.001^{* *}$ & 0.03 & $\mathrm{H}, \mathrm{M}>\mathrm{L}$ \\
\hline I6 & 2.37 & 0.92 & 2.77 & 0.81 & 2.81 & 1.01 & 11.01 & 493 & $0.000^{* * *}$ & 0.04 & $\mathrm{H}, \mathrm{M}>\mathrm{L}$ \\
\hline I7 & 2.92 & 1.12 & 3.24 & 0.80 & 3.28 & 1.02 & 6.16 & 493 & $0.002^{* *}$ & 0.02 & $\mathrm{H}, \mathrm{M}>\mathrm{L}$ \\
\hline I8 & 2.96 & 0.93 & 3.23 & 0.86 & 3.28 & 1.18 & 4.51 & 493 & $0.011 *$ & 0.02 & $\mathrm{H}, \mathrm{M}>\mathrm{L}$ \\
\hline Total D1 & 3.20 & 0.78 & 3.44 & 0.62 & 3.55 & 0.77 & 10.17 & 493 & $0.000^{* * *}$ & 0.04 & $\mathrm{H}>\mathrm{M}>\mathrm{L}$ \\
\hline \multicolumn{12}{|l|}{ D2: Perceptions } \\
\hline I9 & 1.15 & 0.48 & 1.07 & 0.26 & 1.21 & 0.52 & 4.24 & 493 & $0.015^{*}$ & 0.02 & $\mathrm{H}>\mathrm{M}$ \\
\hline I10 & 1.09 & 0.29 & 1.03 & 0.17 & 1.14 & 0.35 & 6.56 & 493 & $0.002^{* *}$ & 0.03 & $\mathrm{H}>\mathrm{M}$ \\
\hline I11 & 1.28 & 0.70 & 1.24 & 0.49 & 1.31 & 0.71 & 0.44 & 493 & 0.647 & 0.00 & $\mathrm{H}, \mathrm{M}, \mathrm{L}$ \\
\hline $\mathrm{I} 12$ & 1.45 & 1.01 & 1.61 & 0.94 & 1.56 & 0.89 & 1.11 & 493 & 0.329 & 0.00 & $\mathrm{H}, \mathrm{M}, \mathrm{L}$ \\
\hline $\mathrm{I} 13$ & 1.32 & 0.57 & 1.23 & 0.42 & 1.34 & 0.64 & 1.78 & 493 & 0.170 & 0.01 & $\mathrm{H}, \mathrm{M}, \mathrm{L}$ \\
\hline $\mathrm{I} 15$ & 1.05 & 0.22 & 1.06 & 0.23 & 1.07 & 0.26 & 0.34 & 493 & 0.711 & 0.00 & $\mathrm{H}, \mathrm{M}, \mathrm{L}$ \\
\hline I16 & 1.22 & 0.80 & 1.17 & 0.50 & 1.19 & 0.53 & 0.23 & 493 & 0.794 & 0.00 & $\mathrm{H}, \mathrm{M}, \mathrm{L}$ \\
\hline I17 & 1.67 & 1.13 & 1.77 & 1.13 & 1.95 & 1.24 & 2.58 & 493 & 0.076 & 0.01 & $\mathrm{H}, \mathrm{M}, \mathrm{L}$ \\
\hline I18 & 1.09 & 0.29 & 1.07 & 0.26 & 1.12 & 0.39 & 1.13 & 493 & 0.324 & 0.00 & $\mathrm{H}, \mathrm{M}, \mathrm{L}$ \\
\hline I19 & 1.04 & 0.19 & 1.06 & 0.23 & 1.02 & 0.14 & 1.53 & 493 & 0.218 & 0.01 & $\mathrm{H}, \mathrm{M}, \mathrm{L}$ \\
\hline $\mathrm{I} 20$ & 1.44 & 0.93 & 1.23 & 0.61 & 1.28 & 0.79 & 2.94 & 493 & 0.054 & 0.01 & $\mathrm{H}, \mathrm{M}, \mathrm{L}$ \\
\hline I21 & 1.32 & 0.69 & 1.21 & 0.65 & 1.21 & 0.52 & 1.62 & 493 & 0.198 & 0.01 & $\mathrm{H}, \mathrm{M}, \mathrm{L}$ \\
\hline $\mathrm{I} 22$ & 1.14 & 0.42 & 1.10 & 0.38 & 1.12 & 0.33 & 0.48 & 493 & 0.619 & 0.00 & $\mathrm{H}, \mathrm{M}, \mathrm{L}$ \\
\hline $\mathrm{I} 24$ & 1.10 & 0.30 & 1.07 & 0.26 & 1.02 & 0.14 & 5.39 & 493 & $0.005^{* *}$ & 0.02 & $\mathrm{H}<\mathrm{L}$ \\
\hline $\mathrm{I} 25$ & 1.41 & 0.84 & 1.28 & 0.56 & 1.28 & 0.68 & 1.87 & 493 & 0.156 & 0.01 & $\mathrm{H}, \mathrm{M}, \mathrm{L}$ \\
\hline I26 & 1.73 & 1.20 & 1.49 & 0.89 & 1.95 & 1.10 & 7.39 & 493 & $0.001 * *$ & 0.03 & $\mathrm{H}>\mathrm{M}$ \\
\hline $\mathrm{I} 27$ & 1.55 & 0.81 & 1.41 & 0.74 & 1.40 & 0.65 & 2.21 & 493 & 0.111 & 0.01 & $\mathrm{H}, \mathrm{M}, \mathrm{L}$ \\
\hline $\mathrm{I} 28$ & 1.09 & 0.29 & 1.07 & 0.26 & 1.12 & 0.39 & 1.13 & 493 & 0.324 & 0.00 & $\mathrm{H}, \mathrm{M}, \mathrm{L}$ \\
\hline I 29 & 2.05 & 1.23 & 1.75 & 0.89 & 2.07 & 1.27 & 3.75 & 493 & 0.024 * & 0.01 & $\mathrm{H}>\mathrm{M}$ \\
\hline I30 & 1.54 & 0.81 & 1.76 & 1.10 & 1.32 & 0.65 & 11.33 & 493 & $0.000^{* * *}$ & 0.04 & $\mathrm{H}<\mathrm{M}$ \\
\hline I31 & 1.40 & 0.74 & 1.38 & 0.83 & 1.36 & 0.80 & 0.11 & 493 & 0.892 & 0.00 & $\mathrm{H}, \mathrm{M}, \mathrm{L}$ \\
\hline I32 & 1.23 & 0.48 & 1.21 & 0.58 & 1.19 & 0.40 & 0.25 & 493 & 0.775 & 0.00 & $\mathrm{H}, \mathrm{M}, \mathrm{L}$ \\
\hline I34 & 2.67 & 1.34 & 2.18 & 1.06 & 2.28 & 1.35 & 6.34 & 493 & $0.002^{* *}$ & 0.02 & $\mathrm{H}, \mathrm{M}>\mathrm{L}$ \\
\hline Total D2 & 1.35 & 0.30 & 1.29 & 0.22 & 1.33 & 0.26 & 2.13 & 493 & 0.120 & 0.01 & H, M, L \\
\hline \multicolumn{12}{|l|}{ D3: Skills } \\
\hline I35 & 3.58 & 1.00 & 3.85 & 0.76 & 4.07 & 1.04 & 11.60 & 493 & $0.000^{* * *}$ & 0.04 & $\mathrm{H}>\mathrm{L}$ \\
\hline I36 & 2.46 & 1.20 & 2.90 & 1.08 & 3.53 & 1.28 & 35.26 & 493 & $0.000^{* * *}$ & 0.13 & $\mathrm{H}>\mathrm{M}>\mathrm{L}$ \\
\hline I37 & 3.79 & 0.93 & 3.93 & 0.59 & 4.07 & 0.86 & 5.01 & 493 & $0.007^{* *}$ & 0.02 & $\mathrm{H}>\mathrm{L}$ \\
\hline I38 & 2.44 & 1.10 & 2.99 & 1.10 & 3.47 & 1.23 & 34.90 & 493 & $0.000^{* * *}$ & 0.12 & $\mathrm{H}>\mathrm{M}>\mathrm{L}$ \\
\hline I39 & 3.50 & 0.85 & 3.52 & 0.90 & 4.03 & 0.71 & 24.28 & 493 & $0.000^{* * *}$ & 0.10 & $\mathrm{H}>\mathrm{M}, \mathrm{L}$ \\
\hline $\mathrm{I} 40$ & 3.82 & 0.99 & 4.08 & 0.65 & 4.07 & 0.90 & 4.70 & 493 & $0.009^{* *}$ & 0.02 & $\mathrm{H}, \mathrm{M}>\mathrm{L}$ \\
\hline Total D3 & 3.26 & 0.62 & 3.54 & 0.51 & 3.87 & 0.61 & 47.06 & 493 & $0.000^{* * *}$ & 0.16 & $\mathrm{H}>\mathrm{M}>\mathrm{L}$ \\
\hline Total & 2.60 & 0.33 & 2.76 & 0.24 & 2.92 & 0.34 & 43.72 & 493 & $0.000^{* * *}$ & 0.15 & $\mathrm{H}>\mathrm{M}>\mathrm{L}$ \\
\hline
\end{tabular}

* Significant $p<0.05 ;{ }^{* *}$ Significant $p<0.01 ;{ }^{* * *}$ Significant $p<0.001$. Source: Authors' own work (2021).

We did find statistically significant differences in the Skills dimension in Items 35, $36,37,38,39$, and 40 and in the overall dimension, with high-achieving children scoring higher. From a general standpoint, these schoolchildren would have better personal and social skills for conflict resolution than their medium- and low- performing peers. After performing a multivariate analysis between the academic performance variable and each dimension and the total score in the questionnaire, these statistically significant differences were confirmed, with $p<0.001$ (Concept dimension $\mathrm{F}=1194.46, p=0.000$; Dimension of 
perception $\mathrm{F}=1809.08, p=0.000$; Skills dimension $\mathrm{F}=1750.25, p=0.000$; Total $\mathrm{F}=4245.04$, $p=0.000)$.

Finally, in the Table 6, we found the following results when relating each dimension to gender and academic performance after comparing averages.

Table 6. Relationship between dimensions, gender, and academic performance.

\begin{tabular}{cccccccc}
\hline \multirow{2}{*}{ Gender } & $\begin{array}{c}\text { Academic } \\
\text { Performance }\end{array}$ & \multicolumn{2}{c}{ Conceptualization } & \multicolumn{2}{c}{ Perceptions } & \multicolumn{2}{c}{ Skills } \\
\cline { 3 - 7 } & Male & $\mathbf{M}$ & SD & $\mathbf{M}$ & SD & M & SD \\
\hline \multirow{2}{*}{ Female } & Low & 3.08 & 0.81 & 1.47 & 0.32 & 2.85 & 0.44 \\
& Medium & 3.42 & 0.67 & 1.30 & 0.19 & 3.13 & 0.33 \\
& High & 3.49 & 0.65 & 1.35 & 0.29 & 3.38 & 0.47 \\
\cline { 2 - 7 } & Total & 3.32 & 0.74 & 1.38 & 0.29 & 3.12 & 0.48 \\
& Low & 3.34 & 0.72 & 1.19 & 0.16 & 3.80 & 0.32 \\
& Medium & 3.45 & 0.59 & 1.28 & 0.24 & 3.87 & 0.39 \\
& High & 3.60 & 0.85 & 1.31 & 0.23 & 4.29 & 0.35 \\
\hline \multirow{2}{*}{ Total } & Total & 3.49 & 0.75 & 1.27 & 0.22 & 4.03 & 0.42 \\
& Low & 3.20 & 0.78 & 1.35 & 0.30 & 3.26 & 0.62 \\
& Medium & 3.44 & 0.63 & 1.29 & 0.22 & 3.54 & 0.51 \\
& High & 3.55 & 0.77 & 1.33 & 0.26 & 3.87 & 0.61 \\
\cline { 2 - 7 } & Total & 3.41 & 0.75 & 1.32 & 0.26 & 3.59 & 0.64 \\
\hline
\end{tabular}

Source: Authors' own work (2021).

Boys and girls with higher academic performance exhibited greater knowledge of the concepts of bullying and cyberbullying (boys $\mathrm{M}=3.49, \mathrm{SD}=0.65$; girls $\mathrm{M}=3.60, \mathrm{SD}=0.85$ ). High achieving girls had higher scores than the rest of the medium and low achievers in terms of perceptions as a victim, aggressor, or witness $(\mathrm{M}=1.31, \mathrm{SD}=0.23 ; \mathrm{M}=1.28$, $\mathrm{SD}=0.24 ; \mathrm{M}=1.19, \mathrm{SD}=0.16$, respectively), a trend not observed in boys since it was the low achieving boys who had the highest scores $(\mathrm{M}=1.47, \mathrm{SD}=0.32)$. The highest performing girls and boys both demonstrated greater personal and social skills for conflict resolution (boys $\mathrm{M}=3.38, \mathrm{SD}=0.47$; girls $\mathrm{M}=4.29$, $\mathrm{SD}=0.35$ ). Within the high-performing group, girls stood out over boys in terms of knowledge of the concepts and particularly in existing skills, with similar results appearing in the perceptions dimension. Boys and girls with lower academic performance gave the opposite results to those with high performance, with the exception of low-performing boys in the perceptions dimension. Finally, a multivariate analysis between the variables confirmed these statistically significant differences, with $p$ values $<0.001$ (Concept Dimension $\mathrm{F}=495.26, p=0.000$; Perception Dimension $\mathrm{F}=1121.87, p=0.000$; Skills Dimension $\mathrm{F}=621.02, p=0.000$; Total $\mathrm{F}=1770.14, p=0.000)$.

To conclude this section, a multilevel analysis was carried out considering school type and setting with the scores in each dimension and the total score for the questionnaire, gender, and academic performance. The results indicated that all the factors of the model had a significant influence on the dependent variables, the scores in each dimension, and the overall instrument score. In other words, both the level 1 independent variablesgender and academic performance-and the level 2 variables_-school type and settingcontributed to the variance of the students' questionnaire results $(p<0.05)$, although the level 1 variables explained more of the variance of the results.

\section{Discussion}

The processes of bullying and cyberbullying can cause serious problems in the schoolchildren who are the victims of them [57,58]. Many studies have reported the various psychological and emotional problems that could arise [34,37,38,59-61]. This means it is essential to have action protocols in schools [62]. In this study, we highlighted the existing protocol in the Spanish Autonomous Community of Castilla-La Mancha and its embodiment in an evaluation instrument. This may be interesting for the generalization 
of a national protocol on school bullying that seeks to unify action criteria, including evaluation, for all of the autonomous communities in Spain.

In addition, strategies need to be developed along with dynamic content for schoolchildren to help them develop conflict resolution skills and emotional intelligence [27]. Working with the peer group is essential [63] in order to ensure that they can get along with each other [64] and avoid self-concealment, which sometimes occurs in cases of harassment [56]. Teaching work is of outstanding importance, and the initial and continuous training of teachers in specific strategies and activities is essential to prevent and intervene in relationship problems between peers [65] from the perspective of victims, aggressors, or witnesses. Empowering students with strategies and knowledge that facilitate detection and intervention before these situations become serious is essential in order to prevent them in the future as well as to properly deal with them in the present. Giving students knowledge and assessing them from an early age will promote prevention of these situations as well as intervention, bearing in mind the importance of risk and protection factors [66]. This has been the fundamental purpose of this study, work in schools promotes well-being in childhood and adolescence [67].

In terms of the results and our general objective with this study, we found the highest scores in the Skills dimension, which emphasizes the need for tutorial action work with students. The results were also high for the Conceptualization dimension, although it should be noted that the Cyberbullying subdimension had lower mean scores than the Bullying subdimension. Within the Perceptions dimension, the highest-scoring item was Item 34, related to witnessing rejection or isolation on social networks or the internet. It is also worth noting that all of the participants stated never having suffered, perpetrated, or witnessed conduct related to sexual abuse. In the Skills dimension, having friends inside and outside the school environment (Item 40) had the highest mean score.

In relation to our specific objectives, despite a balance between the genders in the sample, we did find statistically significant differences by gender with moderate to large effect sizes. In Conceptualization and Skills, girls demonstrated greater knowledge of the concepts of bullying and cyberbullying and had better personal and social skills in terms of conflict resolution than boys. In the Perceptions dimension, boys scored higher in the three subdimensions, Victim, Aggressor, and Witness. Other studies have reported similar findings of differences between the genders [27,68-74]. The gender of students has been found to be a fundamental variable to consider when studying bullying [56], including cyberbullying $[75,76]$, particularly with regard to internalization and externalization of violent behaviors and attitudes [77], and it is important to include the analysis of the greater vulnerability to bullying in LGTB students [78].

In terms of academic performance, we grouped the results into three categories, high, medium, and low. According to the ANOVA, there were generally statistically significant differences in the Conceptualization dimension in the medium and high levels, compared to low-level students. High- and medium-performing students demonstrated greater knowledge of the concepts of bullying and cyberbullying. In the Victim subdimension of the Perceptions dimension, there were some statistically significant differences between highachieving children and medium performers. In the other two subdimensions, Aggressor and Witness, there were notable differences between the three performance levels. In the Skills dimension, high-level students had higher scores, demonstrating more personal and social skills for conflict resolution than students who performed at medium and low levels. The academic performance of those involved is a variable to consider in bullying and cyberbullying behaviors [15,72,79-83], whether one is considering victims or bullies [84]. Bullying hinders the teaching and learning processes in schools since the students involved could have very different levels of school performance, especially where there is physical violence [85], and therefore it should not be considered as something external to school dynamics [75].

On comparing the results of the questionnaire with the gender of the students and their performance, higher-performing boys and girls demonstrated greater knowledge 
of the conceptual terms and greater personal and social skills. There was a disparity in the results for the perceptions dimension, with girls demonstrating lower perceptions as victims, aggressors or witnesses, and greater personal and social skills. In addition, the multilevel analysis indicated that the school type and setting also had an impact on the results, although to a lesser degree than gender and academic performance. In short, our study confirms the impact of these variables and the importance of considering them when looking at the phenomena of bullying and cyberbullying, in line with conclusions from other studies [66].

One of the limitations of our study is its focus on the region of Castilla-La Mancha, and future work could broaden the scope to other areas, although the conceptual basis of the regulatory framework is similar in other regions such as Andalucía. Expanding this research to other regions will also allow the study of how Items 14, 23, and 33 operate, which are related to sexual abuse from the point of view of the victim, aggressor, and witness. Furthermore, a new broader application of the instrument will allow us to carry out a new confirmatory factor analysis and see whether the non-normal distribution is maintained for the items in dimension 2, Perceptions.

Finally, we would like to emphasize the importance of tutorial action in schools [86], including anti-bullying programs [87]. Topics such as social skills, group dynamics, decisionmaking, self-esteem and self-concept, and emotional intelligence are essential in the teaching and learning processes [88]. The creation of positive links between students promotes peaceful coexistence based on mutual respect and equal opportunities.

Author Contributions: A.P.-R. and R.G.-P. designed the study, collected and analyzed the data, and wrote the manuscript. A.C.-M. and M.I.M.-G. contributed to the interpretation of the data and wrote, revised, and refined the manuscript. A.P.-R., R.G.-P., A.C.-M., and M.I.M.-G. participated in sending the article to the journal. All authors have read and agreed to the published version of the manuscript.

Funding: The study was supported by the University of Castilla-La Mancha (UCLM).

Institutional Review Board Statement: The pertinent authorizations were obtained from the educational administrations and families involved.

Informed Consent Statement: Informed consent was obtained from all subjects involved in the study.

Data Availability Statement: Due to the anonymity and confidentiality of the data obtained, the authors have not reported any of the data obtained, the purpose of which is exclusively the development of this research.

Acknowledgments: The authors wish to highlight the enormous gratitude towards the collaborating educational institutions mentioned above.

Conflicts of Interest: A.P.-R., R.G.-P., A.C.-M., and M.I.M.-G. declare that they have no commercial interest in the development of this investigation. The evaluation instrument used is a patent of the authors of the article.

\section{References}

1. Ministerio de Educación, Cultura y Deporte. Guía para la Comunidad Educativa de Prevención y Apoyo a las Víctimas de Ciberacoso en el Contexto Escolar; Centro Nacional de Innovación e Investigación Educativa, Ministerio de Educación, Cultura y Deporte: Madrid, Spain, 2017.

2. Ministerio de Educación, Cultura y Deporte. Guía para la Comunidad Educativa de Prevención y Apoyo a las Víctimas de Violencia Escolar; Centro Nacional de Innovación e Investigación Educativa, Ministerio de Educación, Cultura y Deporte: Madrid, Spain, 2017.

3. Ministerio de la Presidencia, Relaciones con las Cortes y Memoria Democrática. Ley Orgánica 1/2015, de 30 de marzo, por la que se modifica la Ley Orgánica 10/1995, de 23 de noviembre, del Código Penal. Boletín Of. Estado 2015, 77, 27061-27176. Available online: https: / / cutt.ly /5hAw161 (accessed on 25 March 2020).

4. Olweus, D. Bullying at School: What We Know and What We Can Do; Blackwell: Malden, MA, USA, 1993.

5. Avilés, J.M. Victimización percibida y bullying. Factores diferenciales entre víctimas. Boletín Psicol. 2009, 95, 7-28. Available online: https:/ / cutt.ly/ihP5cFi (accessed on 14 April 2020).

6. Cerezo-Ramírez, F.; Sánchez, C.; Ruiz, C.; Arense, J. Roles en bullying de adolescentes y preadolescentes, y su relación con el clima social y los estilos educativos parentales. Rev. Psicodidáct. 2015, 20, 139-155. [CrossRef] 
7. Postigo, S.; González, R.; Montoya, I.; Ordoñez, A. Theoretical proposals in bullying research: A review. An. Psicol. 2013, 29, 413-425. [CrossRef]

8. Falla, D.; Sánchez, S.; Casas, J.A. What Do We Know about Bullying in Schoolchildren with Disabilities? A Systematic Review of Recent Work. Sustainability 2021, 13, 416. [CrossRef]

9. Machimbarrena, J.M.; Garaigordobil, M. Bullying/Cyberbullying en quinto y sexto curso de primaria: Diferencias entre centros públicos y privados. An. Psicol. 2017, 33, 319-326. [CrossRef]

10. Sainio, M.; Veenstra, R.; Huitsing, G.; Salmivalli, C. Victims and their defenders: A dyadic approach. Int. J. Behav. Dev. 2010, 35, 144-151. [CrossRef]

11. Salmivalli, C.; Voeten, M.; Poskiparta, E. Bystanders matter: Associations between reinforcing, defending, and the frequency of bullying behavior in classrooms. J. Clin. Child Adolesc. Psychol. 2011, 40, 668-676. [CrossRef]

12. Veenstra, R.; Lindenberg, S.; Munniksma, A.; Dijkstra, J.K. The Complex Relation Between Bullying, Victimization, Acceptance, and Rejection: Giving Special Attention to Status, Affection, and Sex Differences. Child Dev. 2010, 81, 480-486. [CrossRef] [PubMed]

13. De la Caba, M.A.; López, R. La agresión entre iguales en la era digital: Estrategias de afrontamiento de los estudiantes del último ciclo de Primaria y del primero de Secundaria. Rev. Educ. 2013, 362, 247-272. [CrossRef]

14. Ruiz, R.; Riuró, M.; Tesouro, M. Estudio del bullying en el ciclo superior de primaria. Educ. XX1 2015, 18, 345-368. [CrossRef]

15. Arnaiz, P.; Cerezo, F.; Giménez, A.M.; Maquilón, J.J. Conductas de ciberadicción y experiencias de cyberbullying entre adolescentes. An. Psicol. 2016, 32, 761-769. [CrossRef]

16. González, V.; Prendes, M.P.; López, J.A. Víctimas de ciberacoso: Estudio descriptivo en la Región de Murcia. In Tecnología, Innovación e Investigación en los Procesos de Enseñanza-Aprendizaje; Roig-Vila, R., Ed.; Ediciones Octaedro: Barcelona, Spain, 2016; pp. 1661-1669.

17. Cabello, E.; Pérez, N.; Ros, A.; Filella, G. Los programas de educación emocional happy 8-12 and happy 12-16. Evaluación de su impacto en las emociones y el bienestar. Rev. Orientac. Psicopedag. 2019, 30, 53-66. [CrossRef]

18. Calvo, A.; Manteca, F. Barreras y Ayudas Percibidas por los Estudiantes en la Transición entre la Educación Primaria y Secundaria. REICE Rev. Iberoam. Sobre Calid. Efic. Cambio Educ. 2016, 14, 49-64. [CrossRef]

19. Casas, J.A.; Del-Rio, R.; Ortega-Ruiz, R. Bullying and cyberbullying: Convergent and divergent predictor variables. Comput. Hum. Behav. 2013, 29, 580-587. [CrossRef]

20. Echeburúa, E. Factores de riesgo y factores de protección en la adicción a las nuevas tecnologías y Redes Sociales en jóvenes y adolescentes. Rev. Española Drogodepend. 2012, 4, 435-448. Available online: https://cutt.ly/OhP6LTN (accessed on 2 April 2020).

21. Gómez, P.; Harris, S.K.; Barreiro, C.; Isorna, M.; Rial, A. Profiles of Internet use and parental involvement, and rates of online risks and problematic Internet use among Spanish adolescents. Comput. Hum. Behav. 2017, 75, 826-833. [CrossRef]

22. Kowalski, R.M.; Giumetti, G.W.; Schroeder, A.N.; Lattanner, M.R. Bullying in the digital age: A critical review and meta-analysis of cyberbullying research among youth. Psychol. Bull. 2014, 140, 1073-1137. [CrossRef]

23. Sonone, S.S.; Sankhla, M.S.; Kumar, R. Cyber Bullying. In Combating the Exploitation of Children in Cyberspace: Emerging Research and Opportunities; Sonone, S.S., Sankhla, M.S., Kumar, R., Eds.; IGI Global: Hershey, PA, USA, 2021; pp. 1-18. [CrossRef]

24. Reyes, Y.; Acuña, J. Acoso escolar y disrupción del aprendizaje en estudiantes de la secundaria de Chilpancingo, México. Rev. Innova Educ. 2020, 2, 413-430. [CrossRef]

25. Ang, R.P. Adolescent cyberbullying: A review of characteristics, prevention and intervention strategies. Aggress. Violent Behav. 2015, 25, 35-42. [CrossRef]

26. Calmaestra, J.; Rodríguez-Hidalgo, A.J.; Mero-Delgado, O.; Solera, E. Cyberbullying in Adolescents from Ecuador and Spain: Prevalence and Differences in Gender, School Year and Ethnic-Cultural Background. Sustainability 2020, 12, 4597. [CrossRef]

27. Rey, L.; Quintana-Orts, C.; Mérida-López, S.; Extremera, N. Inteligencia emocional y cibervictimización en adolescentes: El género como moderador. Comunicar 2018, 56, 9-18. [CrossRef]

28. Zhang, H.; Sun, X.; Chen, L.; Yang, H.; Wang, Y. The Mediation Role of Moral Personality Between Childhood Psychological Abuse and Cyberbullying Perpetration Attitudes of College Students. Front. Psychol. 2020, 11, 1215. [CrossRef]

29. Chao, C.M.; Kao, K.Y.; Yu, T.K. Reactions to Problematic Internet Use Among Adolescents: Inappropriate Physical and Mental Health Perspectives. Front. Psychol. 2020, 11, 1782. [CrossRef]

30. Ruiz, M.; Santibáñez, R.; Laespada, M.T. Acoso escolar adolescentes víctimas y agresores. La implicación en ciclos de violencia. Bordón. Rev. Pedagog. 2020, 72, 117-132. [CrossRef]

31. Junta de Comunidades de Castilla-La Mancha. Resolución 18 de enero de 2017, de la Consejería de Educación, Cultura y Deportes. Protocolo de actuación ante situaciones de acoso escolar en los centros docentes públicos no universitarios de Castilla La Mancha. D. Off. Castilla Mancha 2017, 14, 1177-1195. Available online: https:/ / cutt.ly/kmyPqPF (accessed on 20 February 2019).

32. Junta de Andalucía. ORDEN de 20 de junio de 2011, por la que se adoptan medidas para la promoción de la convivencia en los centros docentes sostenidos con fondos públicos y se regula el derecho de las familias a participar en el proceso educativo de sus hijos e hijas. Boletín Of. Junta Andal. 2011, 132, 6-27. Available online: https:/ / cutt.ly/PhAwzJl (accessed on 23 February 2019).

33. Amaraphibal, A. Cyber-bullying victimization among youths: Risk factor, mental health impacts and reporting to the third person. Res. Methodol. Cogn. Sci. 2016, 14, 60-73. Available online: https:/ / cutt.ly/bhP5yhz (accessed on 16 September 2020).

34. Espelage, D.L.; Holt, M.K. Suicidal ideation and school bullying experiences after controlling for depression and delinquency. J. Adolesc. Health 2013, 53, 27-31. [CrossRef] 
35. Fernández-Sogorb, A.; Sanmartín, R.; Vicent, M.; García-Fernández, J.M. Latent Profiles of Anxious Children and Their Differences in Aggressive Behavior. Sustainability 2020, 12, 6199. [CrossRef]

36. Machmutow, K.; Perren, S.; Sticca, F.; Alsaker, F.D. Peer victimization and depressive symptoms: Can specific coping strategies buffer the negative impact of cybervictimization? Emot. Behav. Difficulties 2012, 17, 403-420. [CrossRef]

37. Martín, J.; Ruiz, E.; Martínez, R. Desajuste Psicológico de las Víctimas de Acoso Escolar: Un Análisis Evolutivo Desde la Educación Primaria Hasta la Secundaria; Colegio Oficial de Psicólogos de Madrid y Fundación Atresmedia: Madrid, Spain, 2014.

38. Palomares-Ruiz, A.; Oteiza-Nascimento, A.; Toldos, M.A.; Serrano-Marugán, I.; Martín-Babarro, J. Bullying and depression: The moderating effect of social support, rejection and victimization profile. An. Psicol. 2019, 35, 1-10. [CrossRef]

39. Díaz-Aguado, M.J.; Martín, G. Convivencia y aprendizaje escolar en la adolescencia desde una perspectiva de género. Psicothema 2011, 23, 252-259. Available online: https: / / cutt.ly/UhP6syo (accessed on 4 April 2020).

40. López, V.; Bilbao, M.A.; Rodríguez, J.I. La sala de clases sí importa: Incidencia del clima de aula sobre la percepción de intimidación y victimización entre escolares. Univ. Psychol. 2012, 11, 91-101. [CrossRef]

41. Cava, M.J.; Ayllón, E.; Tomás, I. Coping Strategies against Peer Victimization: Differences According to Gender, Grade, Victimization Status and Perceived Classroom Social Climate. Sustainability 2021, 13, 2605. [CrossRef]

42. García, J.; Orellana, M.C. Variables Psicológicas Moduladoras de la Autodefinición del Perfil en Procesos de Acoso Escolar: El papel del género y el currículum escolar. Eur. J. Educ. Psychol. 2008, 1, 41-55. [CrossRef]

43. Dembo, R.; Krupa, J.M.; Faber, J.; DiClemente, R.J.; Wareham, J.; Schmeidler, J. An Examination of Gender Differences in Bullying among Justice-involved Adolescents. Deviant Behav. 2019, 42, 268-287. [CrossRef]

44. García-Perales, R.; Jiménez, C. Relación entre repetición de curso, rendimiento académico e igualdad en educación. Las aportaciones de PISA. Rev. Educ. Política Soc. 2019, 4, 84-108. Available online: https:/ / cutt.ly/DhAqhI8 (accessed on 16 May 2020).

45. Faryadi, Q. Cyber Bullying and Academic Performance. Int. J. Comput. Eng. Res. 2011, 1, 23-30. Available online: https: / / cutt.ly/2kJ00TS (accessed on 22 March 2020).

46. Huang, L. Exploring the relationship between school bullying and academic performance: The mediating role of students' sense of belonging at school. Educ. Stud. 2020, 46, 1-17. [CrossRef]

47. Lacey, A.; Cornell, D. The Impact of Teasing and Bullying on Schoolwide Academic Performance. J. Appl. Sch. Psychol. 2013, 29, 262-283. [CrossRef]

48. Vieira, M.A.; Handegård, B.H.; Rønning, J.A.; Duarte, C.S.; Mari, J.J.; Bordin, I.A. Do adolescents exposed to peer aggression at school consider themselves to be victims of bullying? The influence of sex and age. Trends Psychiatry Psychother. 2021, 1-29. [CrossRef]

49. Archer, J. Sex Differences in Aggression in Real-World Settings: A Meta-Analytic. Review. Rev. Gen. Psychol. 2004, 8, 291-322. [CrossRef]

50. Steven, D.; Glassner, S.C. Bullying victimization, negative emotions, and substance use: Utilizing general strain theory to examine the undesirable outcomes of childhood bullying victimization in adolescence and young adulthood. J. Youth Stud. 2018, 21, 1232-1249. [CrossRef]

51. Hosozawa, M.; Bann, D.; Fink, E.; Elsden, E.; Baba, S.; Iso, H.; Patalay, P. Bullying Victimisation in Adolescence: Prevalence and Inequalities by Gender, Socioeconomic Status and Academic Performance Across 71 Countries. Socioecon. Status Acad. Perform. Across 2021. [CrossRef]

52. Malhi, P.; Bharti, B. School Bullying and Association with Somatic Complaints in Victimized Children. Indian J. Pediatrics 2021, 1-6. [CrossRef]

53. Muthevhuli, B.J.; Obadire, O.S. Exploring the Effects of Bullying on Primary School Pupils in South Africa. Afr. J. Dev. Stud. 2021, 11, 209-228. [CrossRef]

54. Ministerio de Educación y Formación Profesional. Datos Estadísticos para Enseñanzas no Universitarias; Ministerio de Educación y Formación Profesional: Madrid, Spain, 2019; Available online: https: / / cutt.ly/DhAesTN (accessed on 25 December 2019 ).

55. García-Perales, R.; Palomares, A.; Cebrián, A. Diseño y validación de un instrumento para evaluar el acoso escolar al término de la Educación Primaria. Rev. Esp. Orientac. Psicopedag. 2020, 31, 78-96. [CrossRef]

56. García, A.; Fernández, I. Auto-ocultación del acoso escolar si se es víctima, agresor o testigo, y su vinculación con el bienestar subjetivo. Rev. Virtual Univ. Catól. Norte 2020, 61, 150-165. [CrossRef]

57. Estévez, E.; Jimenez, T.; Moreno, D. Aggressive behavior in adolescence as a predictor of personal, family, and school adjustment problems. Psicothema 2018, 30, 66-73. [CrossRef]

58. Smith, P.K.; Mahdavi, J.; Carvalho, C.; Fisher, S.; Russell, S.; Tippett, N. Cyberbullying: Its nature and impact in secondary school pupils. J. Child Psychol. Psychiatry 2008, 49, 376-385. [CrossRef]

59. Copeland, W.E.; Wolke, D.; Angold, A.; Costello, E.J. Adult psychiatric outcomes of bullying and being bullied by peers in childhood and adolescence. JAMA Psychiatry 2013, 70, 419-426. [CrossRef] [PubMed]

60. Lund, R.; Kragelund, K.; Hjorth, D.; Kiregbaum, M.; Molbo, D.; Due, P.; Christensen, U. Exposure to bullying at school and depression in adulthood: A study of Danish men born in 1953. Eur. J. Public Health 2009, 19, 111-116. [CrossRef] [PubMed]

61. Zwierzynska, K.; Wolke, D.; Lereya, T. Peer victimization in childhood and internalizing problems in adolescence: A prospective longitudinal study. J. Abnorm. Child Psychol. 2013, 41, 309-323. [CrossRef] [PubMed] 
62. Novo, M.; Seijo, D.; Vilariño, M.; Vázquez, M.J. Frecuencia e intensidad en el acoso escolar: ¿qué es qué en la victimización? Rev. Iberoam. Psicol. Salud 2013, 4, 1-15. Available online: https:/ / cutt.ly/2hAelGP (accessed on 25 May 2020).

63. Salmivalli, C. Bullying and the peer group: A review. Aggress. Violent Behav. 2010, 15, 112-120. [CrossRef]

64. Castro-Robles, A.; Niño-Vega, J.; Fernández-Morales, F. El acoso escolar como oportunidad para mejorar la convivencia en el aula. Educ. Humanismo 2020, 22, 1-13. [CrossRef]

65. Palomares-Ruiz, A. Competencias y Empoderamiento Docente. Propuestas de Investigación e Innovación Educativas en Contextos Inclusivos; Editorial Síntesis: Madrid, Spain, 2016.

66. Suárez-García, Z.; Álvarez-García, D.; Rodríguez, C. Predictores de ser víctima de acoso escolar en Educación Primaria: Una revisión sistemática. Rev. Psicol. Educ. J. Psychol. Educ. 2020, 15, 1-15. [CrossRef]

67. Alcántara, S.C.; González-Carrasco, M.; Montserrat, C.; Viñas, F.; Casas, F.; Abreu, D.P. Peer violence in the School Environment and Its Relationship with Subjective Well-Being and Perceived Social Support Among Children and Adolescents in Northeastern Brazil. J. Happiness Stud. 2017, 18, 1507-1532. [CrossRef]

68. Beckman, L.; Hagquist, C.; Hellström, L. Discrepant gender patterns for cyberbullying and traditional bullying. An analysis of Swedish adolescent data. Comput. Hum. Behav. 2013, 29, 1896-1903. [CrossRef]

69. Carbone-Lopez, K.; Esbensen, F.; Brick, B.T. Correlates and consequences of peer victimization: Gender differences in direct and indirect forms of bullying. Youth Violence Juv. Justice 2010, 8, 332-350. [CrossRef]

70. Donoso-Vázquez, T.; Rubio, M.J.; Vilà, R. Las ciberagresiones en función del género. Rev. Investig. Educ. 2017, 35, 197-208. [CrossRef]

71. Giménez-Gualdo, A.M.; Arnaiz-Sánchez, P.; Cerezo-Ramírez, F.; Prodócimo, E. Percepción de docentes y estudiantes sobre el ciberacoso. Estrategias de intervención y afrontamiento en Educación Primaria y Secundaria. Comunicar 2018, 56, 29-38. [CrossRef]

72. Giumetti, G.W.; Kowalski, R.M. Cyberbullying matters: Examining the incremental impact of cyberbullying on outcomes over and above traditional bullying in North America. In Cyberbullying Across the Globe. Gender, Family, and Mental Health; Navarro, R., Yubero, S., Larrañaga, E., Eds.; Springer International Publishing: Cham, Switzerland, 2016; pp. 117-130. [CrossRef]

73. Major, J.; Santoro, N. 'Sensible girls' and 'silly boys': What do teachers need to know about gender? Aust. Educ. Res. 2014, 41, 59-72. [CrossRef]

74. Velasco, M.J.; Álvarez-González, B. Perfiles y percepciones de género en violencia escolar. Rev. Investig. Educ. 2015, 33, $211-231$. [CrossRef]

75. García, C.M.; Romera, E.M.; Ortega, R. Explicative factors of face-to-face harassment and cyberbullying in a sample of primary students. Psicothema 2015, 27, 347-353. [CrossRef]

76. Zsila, A.; Róbert, U.; Griffiths, M.D.; Demetrovics, Z. Gender differences in the association between cyberbullying victimization and perpetration: The role of anger rumination and traditional bullying experiences. Int. J. Ment. Health Addict 2019, 17, $1252-1267$. [CrossRef]

77. Ameli, V.; Meinck, F.; Munthali, A.; Ushie, B.; Langhaug, L. Associations between adolescent experiences of violence in Malawi and gender-based attitudes, internalizing, and externalizing behaviors. Child Abus. Negl. 2017, 67, 305-314. [CrossRef] [PubMed]

78. Larrain, E.; Garaigordobil, M. El Bullying en el País Vasco: Prevalencia y diferencias en función del sexo y la orientación-sexual. Clín. Salud 2020, 31, 147-153. [CrossRef]

79. Álvarez, D.; Álvarez, L.; Núñez, J.C.; González, P. Violencia en los centros educativos y fracaso académico. Rev. Iberoam. Psicol. Salud 2010, 1, 139-153. Available online: https:/ / cutt.ly / ehP75Hm (accessed on 11 June 2020).

80. Comi, S.L.; Argentin, G.; Gui, M.; Origo, F.; Pagani, L. Is it the way they use it? Teachers, ICT and student achievement. Econ. Educ. Rev. 2017, 56, 24-39. [CrossRef]

81. Egeberg, G.; Thorvaldsen, S.; Ronning, J.A. The impact of cyberbullying and cyber harassment on academic achievement. In Digital Expectations and Experiences in Education; Elstad, E., Ed.; Sense Publishers: Rotterdam, The Netherlands, 2016 ; pp. 183-204. [CrossRef]

82. Ferrel, F.; Cuan, A.; Londoño, Z.; Ferrel, L. Factores de riesgo y protectores del bullying escolar en estudiantes con bajo rendimiento de cinco instituciones educativas de Santa Marta, Colombia. Psicogente 2015, 18, 188-205. [CrossRef]

83. Ybarra, M.L.; Espelage, D.L.; Mitchell, K.J. Differentiating youth who are bullied from other victims of peer-aggression: The importance of differential power and repetition. J. Adolesc. Health Off. Publ. Soc. Adolesc. Med. 2014, 55, 293-300. [CrossRef] [PubMed]

84. Al-Raqqad, H.K.; Al-Bourini, E.S.; Al Talahin, F.M.; Aranki, R.M.E. The Impact of School Bullying on Students' Academic Achievement from Teachers Point of View. Int. Educ. Stud. 2017, 10, 44-50. [CrossRef]

85. Albuhairan, F.; Abou, O.; El Sayed, D.; Badri, M.; Alshahri, S.; de Vries, N. The relationship of bullying and physical violence to mental health and academic performance: A cross-sectional study among adolescents in Kingdom of Saudi Arabia. Int. J. Pediatr. Adolesc. Med. 2017, 4, 61-65. [CrossRef] [PubMed]

86. González-Álvarez, M. Formación inicial y permanente de la función tutorial. Aula Encuentro 2018, 20, 26-53. [CrossRef]

87. Gaffney, H.; Ttofi, M.M.; Farrington, D.P. What works in anti-bullying programs? Analysis of effective intervention components. J. Sch. Psychol. 2012, 85, 37-56. [CrossRef]

88. del Pilar Dávila-Soto, R. Programa de tutoría para desarrollar habilidades sociales en las estudiantes. Rev. Identidad 2020, 6, 98-104. [CrossRef] 